\title{
都市気象・ビルエネルギ一連成モデルを用いた 事務所街区内気温の数值シミュレーション NUMERICAL SIMULATION OF AIR-TEMPERATURE AT OFFICE BUILDING DISTRICT WITH INTERACTION MODEL BETWEEN URBAN HEAT-ISLAND AND BUILDING ENERGY-CONSUMPTION
}

\author{
大橋唯太 $^{1} \cdot$ 平野勇二郎 $^{2} \cdot$ 玄地裕 $^{3} \cdot$ 近藤裕昭 $^{4} \cdot$ 亀卦川幸浩 $5 \cdot$ 吉門洋 6 \\ Yukitaka OHASHI, Yujiro HIRANO, Yutaka GENCHI, Hiroaki KONDO, Yukihiro KIKEGAWA \\ and Hiroshi YOSHIKADO

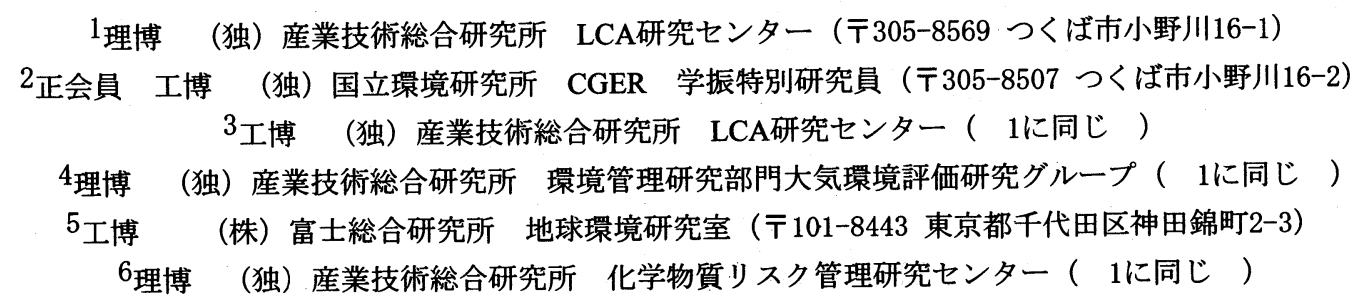

We investigated air-temperature diurnal variations within urban canopy layer, using a coupled model between the urban meteorology and building energy consumption. The main results obtained are as follows. The coupled model reproduces temperature fields during weekdays when a waste heat exists due to energy consumption and cooling needs in buildings, as well as during weekend. The waste heat causes a temperature rising of $1-2{ }^{\circ} \mathrm{C}$ during the weekdays at the Tokyo office area. However, the temperature rising strongly depends on weather conditions (e.g., solar radiation and wind speed); the temperature rising is small when the solar radiation flux and wind speed increase.

Key Words : Urban canopy layer, Anthropogenic heat due to air conditioning operations, Numerical simulation, Distributional observation

\section{1. はじめに}

都市域内の気温は, 人工物による被覆やキャニオン形 状といった街区構造だけでなく, 自動車や空調室外機か らの排熱の影響も強く受けている. 特に, 人工排熱量と 気温との間には相互作用が存在しているため, 街区内の 気温変動を予測するためには, 建物一の熱負荷と冷房シ ステムによる室外への除去熱量を計算する必要がある.

それを可能とする都市気象・ビルエネルギー連成モデル が近年, 近藤・劉 $(1998)^{1)}$ と亀卦川ほか $(2001)^{2)}$, Ashie et al. (2001) ${ }^{3)}$ によって開発されている. これ らのモデルは今後, ヒートアイランド対策や省エネル ギ一策の都市域内への導入や，都市計画などにおいての 熱環境予測の評価に広く利用されることが期待されてい る. その定量的評価をおこなうためにはモデルの計算精 度に関する検証が必要であるが，このような連成モデル
は世界的にも希少であり，それが十分に検討されてきて はいない. 街区内で起こる気温分布の非一様性から考え ても, 街区内の多数の地点で測定された地上気温との比 較が必要であるが，そのような検討についてもされてい ない，そこで本研究では，実際の街区内の多地点で地上 気温の測定を夏季に実施し, 連成モデルによるシミュ レーション結果との比較検討をおこなった.

環境省ヒートアイランド対策委員会の報告(4)によれば, 東京23区のうち事務所系ビルが支配する千代田区や中央 区では，夏季において大気に供給される顕熱のうち50〜 60\%は冷房排熱であることが指摘されており，他用途街 区に比べても冷房排熱の気温上昇一の寄与が大きい. 従って, 事務所系ビルが支配する数百メートル四方の街 区を対象として，実測及び数值シミュレーションをおこ なった. 
神田地区

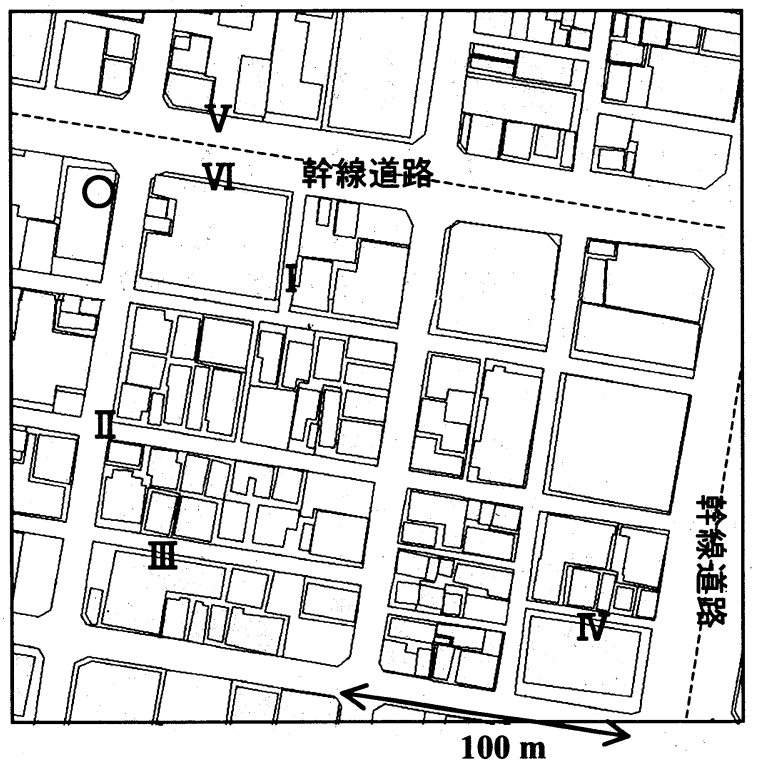

日本橋地区

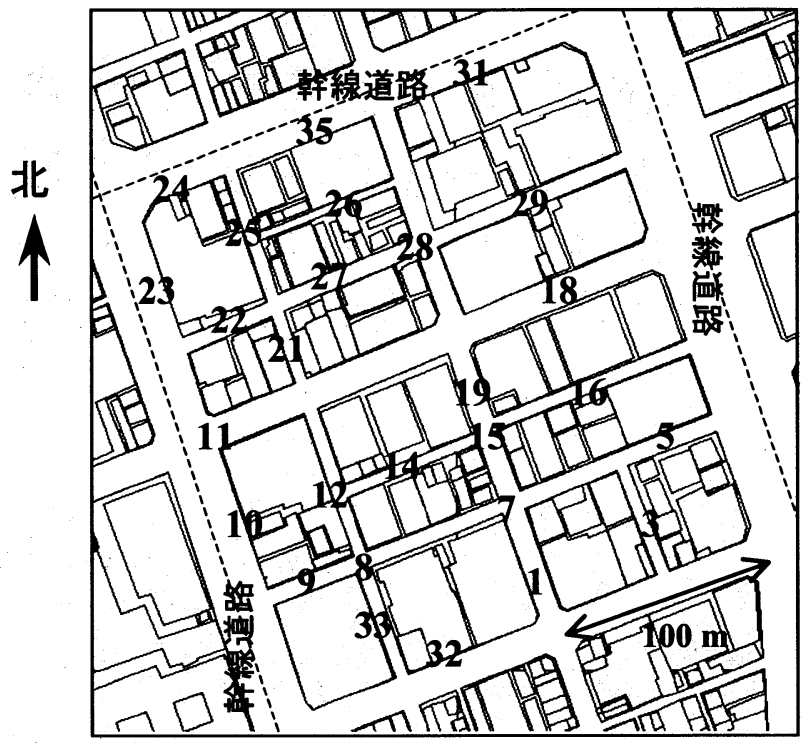

図-1 観測対象街区と気温測定地点

\section{2. 事務所街区内での多地点気温測定}

\section{(1) 観測対象街区}

事務所系ビルが主要を占める東京都千代田区神田，中 央区日本橋の 2 街区で，2002年の平日期間7月29〜 30日， 休日期間 8 月 $10 \sim 11$ 日に地上気温の多地点観測を実施し た. 観測対象街区と気温測定地点を図-1に示寸. 対象街 区の範囲は, 神田街区が東西方向約 $200 \mathrm{~m}$, 南北方向約 $180 \mathrm{~m}$, 日本橋街区は東西方向約 $200 \mathrm{~m}$, 南北方向約 $250 \mathrm{~m}$ で ある. 神田街区で計6地点, 日本橋街区では計27地点の 気温測定ポイントを設けた. 神田街区から南に約 $300 \mathrm{~m}$, 日本橋からは西に約 $1 \mathrm{~km}$ の地点には, 東京管区気象台 (AMeDAS大手町) が存在する.

\section{（2） 観測方法}

測定には, 携帯型温度測定器（ティーアンドディー社 製）を用いた. 日射による測定器の直接加熱を避けるた めに，自作の強制通風管を装着した状態で地上気温の測 定をおこなった. なお，測定器はアスマン式通風温度計 との比較によって, 日射による加熱の影響は小さく, 議 論のうえでは十分な精度であることを確認している. 神 田街区では30分毎（正時と正時半）に，6地点でほぼ同 時に1分間（サンプリング間隔10秒）の固定観測をおこ なった. したがって, 解析には1分間の平均值を用いる. また，同地点においては，放射温度計（ホリバ社製）を 用いた路面温度の測定もおこなった。一方，日本橋街区 では測定地点を多く設けているため, 自転車を使った移 動測定を正時に開始し，27地点での気温測定を $20 \sim 30$ 分 要しておこなった（サンプリング間隔5秒）．各地点で
測定される時間は20〜30秒程度であり，その平均値を解 析に用いた. 各地点で測定された気温は，その測定時刻 がばらばらであるので, 正時への補正を線形内挿によっ ておこなっている. 正時への補正方法としては，固定観 測点で測定された気温の時間変化率を用いる方法5) も る. 街区の気温変化率は, 街区構造, 自動車通過率, 日 射や移流の様子によって篗測地点ごとに異なると考えら れたために, 時間の補正方法として, 上述の観測地点ご とに線形内挿する方法を採用した.

\section{（3）钽測期間中の天気概況}

7月 29〜 30日（以降，平日観測と呼称），8月 10 11日 （以降，休日観測と呼称）とも，日本列島は太平洋高気 圧に覆われており，おおむね天候に恵まれた。 7月29〜 30 日の観測期間の中で, 29日午前中は比較的雲が多かつ たが，午後から翌 30 日までは晴天状態であった. 一方， 8月10〜11日は, ほぼ快晴の状態が継続した。 平日観測 では午前9〜10時に海陸風の交替が見られたが，休日観 測ではそれが見られなかった. 夜間は両期間とも南西風 となっており，風速は休日の方が大きかった．平日観測 は午前中の雲の影響で, 一日を通して休日観測に比べて 気温は低めであった。

\section{3. 連成モデルによるシミュレーションの概要}

\section{（1）モデル構成}

使用したモデルは，既述の近藤・劉（1998） ${ }^{1)}$ と亀卦 川ほか $(2001)^{2)}$ によって開発された都市気象・ビルエ ネルギー連成モデルである. 図-2にモデルの概略図を示 


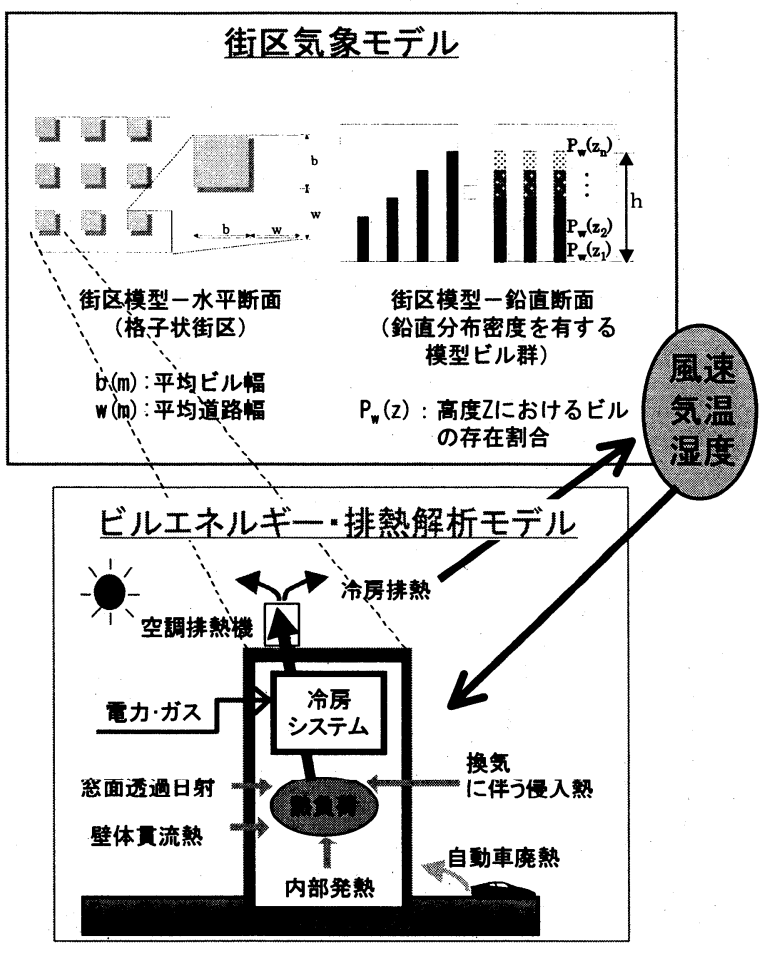

図-2 都市気象・ビルエネルギー連成モデルの模式図

す.このモデルは, 街区気象モデル（以降，CMと呼 称）とビルエネルギー・排熱解析モデル（以降，BEM と呼称）で構成されており，CMで気象場の変動を， BEMによって冷房排熱量の変動を予測する.

CMは数百メートルの街区スケール気象の表現を目的 としており，都市キャノピー層内を鉛直方向に解像化し たモデルである. このモデルでは, 1 格子内に同一の大 きさを持った直方体ビルが整形配列しており，鉛直方向 には高度毎にビルの存在密度が考慮されている. 各気象 要素は鈆直1次元にしか計算されないが，放射環境を3次 元的に扱うことによって, 屋上・東西南北の各壁面と路 面の表面温度や顕熱輸送が計算される. 表面の顕熱輸送 量はユルゲスの式(6)，大気の乱流拡散係数はGamboの式 ${ }^{7)}$ がそれぞれ採用されている.

BEMでは, 建物を1つのボックスとして取り扱うこと で室内の熱収支計算がおこなわれる.ここでは，空面か らの透過日射, 壁体加の貫流熱, 換気に伴う熱の流入, 照明やOA機器, 人体からの発熱量を求めることによっ て建物内一の（䫓熱潜熱それぞれに対しての）熱負荷を 計算する．室内の冷房運転によって，その熱負荷と消費 された電力やガスエネルギーは，排熱として外気へと除 去される. この除去排熱が，CMで計算される気温・湿 度の場に反映されることになる.このモデルの検証は, 実際のビル室内温度と冷房負荷処理量の変動の比較や, 日最大電力需要の気温感応度の比較に関しておこなわれ ている11. 表-1＼cjkstart街区気象モデルにおけるパラメータ設定1),2)

\begin{tabular}{|c|c|c|c|c|c|}
\hline & & \multirow{2}{*}{ アルベド } & \multirow{2}{*}{ 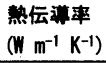 } & \multicolumn{2}{|c|}{ 体積熱容典 } \\
\hline & & & & $\times 10^{6}$ & $\left(\mathrm{~J} \mathrm{~m}^{-3} \mathrm{~K}^{-1}\right)$ \\
\hline \multirow{2}{*}{ 道路 } & $\begin{array}{c}\text { 上層 } \\
\text { (アスファルト) }\end{array}$ & 0.1 & 0.73 & & 2. 06 \\
\hline & $\begin{array}{l}\text { 下層 } \\
\text { (土境) }\end{array}$ & - & 1.00 & & 1.74 \\
\hline \multirow{3}{*}{ ビル } & $\begin{array}{c}\text { 壁 } \\
\text { (コンクリート) }\end{array}$ & 0.2 & 2. 28 & & 2.01 \\
\hline & $\begin{array}{l}\text { 断熱材 } \\
\text { (ポリエチレン発泡板, } \\
\text { 室内側厚さ } 5 \mathrm{~cm} \text { ） }\end{array}$ & - & 0.04 & & 0.06 \\
\hline & $\begin{array}{c}\text { 密 } \\
\text { （側壁面の30\%） }\end{array}$ & 0.4 & - & & - \\
\hline
\end{tabular}

表-2 ビルエネルギー・排熱解析モデルにおけるパラメータ 設定 ${ }^{1), 2)}$

\begin{tabular}{|c|c|}
\hline パラメータ & 設定值 \\
\hline 冷房設定温度 & $26.0{ }^{\circ} \mathrm{C}$ \\
\hline 冷房設定相対湿度 & $50.0 \%$ \\
\hline 冷唇時間带 & (8時より予冷迋転) \\
\hline 熱源權成比 & 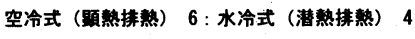 \\
\hline 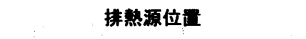 & 屋上 \\
\hline 延床面租に占める冷房面樌の割合 & $60.0 \%$ \\
\hline 外文算入量 & 平日 $5.0 \mathrm{~m}^{3} /\left(\mathrm{m}^{2} \cdot \mathrm{h}\right)$ \\
\hline 在室人員 1 人当たりの占有床面掼 & $5.0 \mathrm{~m}^{2} /$ 人 \\
\hline 人体発熱量 & 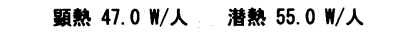 \\
\hline 㝕面の日射透過事 & 0.3 （ブラインドを想定） \\
\hline 単位建物容䆏当たりの空気熱容量 & 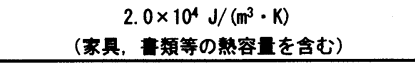 \\
\hline
\end{tabular}

\section{（2）計算条件}

計算は，初期值の影響をできるだけ回避するために， 比較対象日の2日前（7月27日，8月8日）からおこなった。 CMの計算には, 図-1の○印で示された神田街区内ビル の屋上（高さ約 $35 \mathrm{~m}$ ） で観測期間中に測定された天空か らの短波・長波放射量, 東京管区気象台で測定された気 象要素の時間変化率を上端境界条件として与えた. 観測 街区の形状を示すビル幅, 道路幅, ビル密度の鉛直分布 は，東京都GIS（地理情報システム）データの第4次 メッシュレベルでの平均値を用いた. ビル壁面や路面の 物性值に関する設定は，事務所系ビルで一般的なものを 与えている（表-1）.

BEMでの各種パラメータの設定を表-2に示す. 冷房 は平日日中のみの運転とし，ビル屋上からの顕熱，潜熱 排出（空冷式6, 水冷式4の熱源機器構成比）とした. 主 要幹線道路沿いで自動車排熱の気温上昇への寄与が，日 本橋街区を対象とした移動観測から確認されたが，観測 地点のほとんどが位置する街区の内側では自動車排熱の 影響を無視することができたため ${ }^{8}$ ，計算において自動 車排熱は考慮していない。 

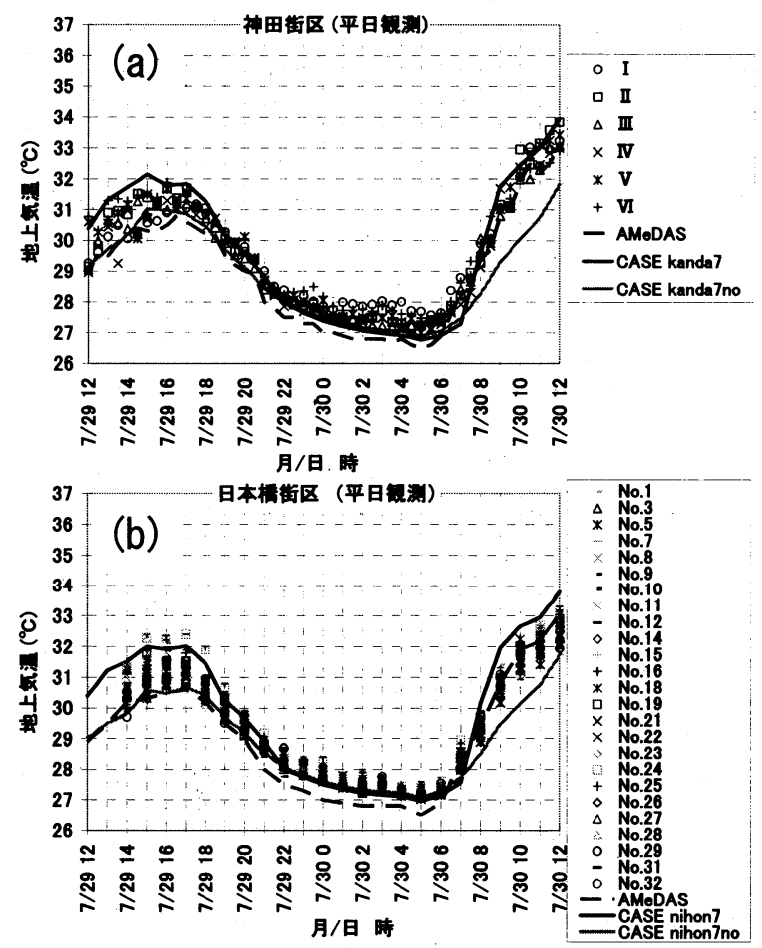

図-3 平日観測期間中の (a) 神田街区，(b) 日本橋街区での観 測結果 (マーカー) と計算結果 (実線) 。濃い実線が ビルの泠房負荷と排熱を考慮した場合, 薄い実線はそ れらを考慮しない場合の計算結果. 破線はAMeDAS大 手町での観測値を示す.

平日観測期間を対象としたシミュレーションでは, ビル内の冷房負荷と外気への排熱を考慮した計算 (CM とBEMの連成計算）をおこなった。一方の休日観測期 間は，お盆休暇の前半に相当しているために，大部分の ビルで人は存在せず空調システムも停止していたことが 予想される. 従って, 休日観測期間を対象としたシミュ レーションでは，ビル内の冷房負荷と外気への排熱を考 慮しない計算 (BEMを連成させずに街区気象モデル単 独での計算) をおこなった。

\section{4. 実測結果とシミュレーション結果の比較}

平日観測と休日観測の期間に神田・日本橋それぞれの 街区で測定された地上気温と，モデルによって計算され た地上気温の時間変化を図-3と図-4に示す. 両街区で観 測された地上気温（マーカー）は，両観測期間とも $\mathrm{AMeDAS}$ 気温 (破線) に比べて日中は最大で $3^{\circ} \mathrm{C}$, 夜は 最大 $1^{\circ} \mathrm{C}$ 高いことがわかる. 平日観測期間のモデル計算 で，冷房負荷・排熱を考慮しない場合（図-3の薄い実線 であるCASE kanda7noとCASE nihon7no）には，日中は AMeDAS気温と同じか, もしくは低めに気温が予測され ている.しかし冷房負荷・排熱を考慮した場合には
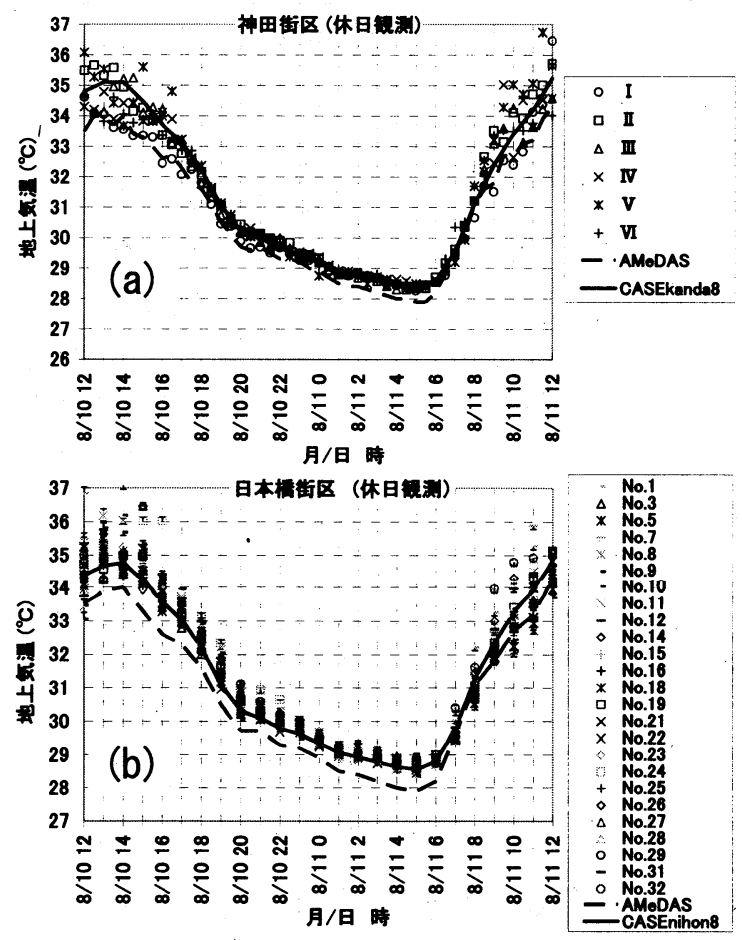

図-4 図-3と同じ.ただし休日観測期間中の結果. 休日のた め, 実線はビルの冷房負荷と排熱を考慮しない計算結 果である.

（図-3の濃い実線であるCASE kanda7とCASE nihon7）, 街区内で実測された気温に近づくことがわかる. 一方, 泠房負荷・排熱を考慮しない休日観測期間の計算 (図4）では，実測された街区内気温のばらつきの間を通る ように予測されている. このように，夏季平日の事務所 街区では冷房排熱による気温上昇は無視できず, 街区内 の気温の予測にはビル内でのエネルギー消費とそれに伴 う冷房排熱をモデル化し, 街区内気象場との相互作用を 考慮した計算が必要であると言える.

また，図-1の神田街区ビル屋上 $35 \mathrm{~m}$ 高度で測定された 気温とモデルによって計算された同高度での気温を比較 してみても，かなり良い一致が見られている（図-5）。 仮に平日観測期間において冷房負荷・排熱を考慮しない 場合には，日中に観測值と計算値の間に大きな乘離が現

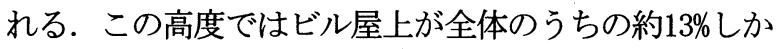
存在しておらず, 他の高度の屋上から排出された大部分 の冷房排熱が乱流拡散で運ばれてくることによって温度 上昇が生じているものと考えられる. 路面温度に関して も，モデル計算値は神田街区6箇所の実測平均値を，平 日・休日観測両期間ともよく再現できていた（図省略）. これらの比較から, 本研究で用いた連成モデルは, 都市 キャノピー層内の温度構造とその日変化をよく再現でき ていると言える. 


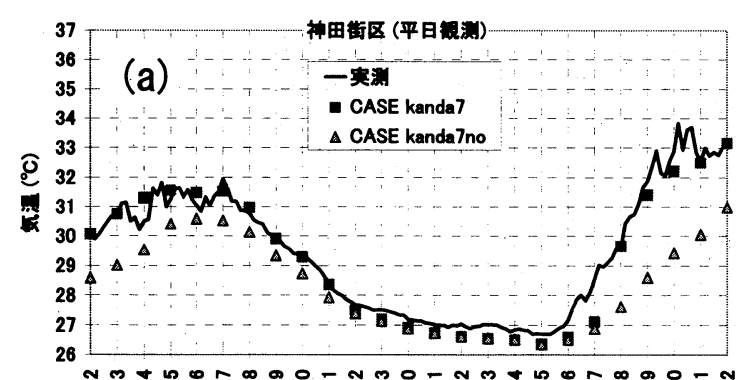

는

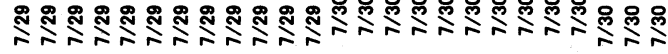
月/日時

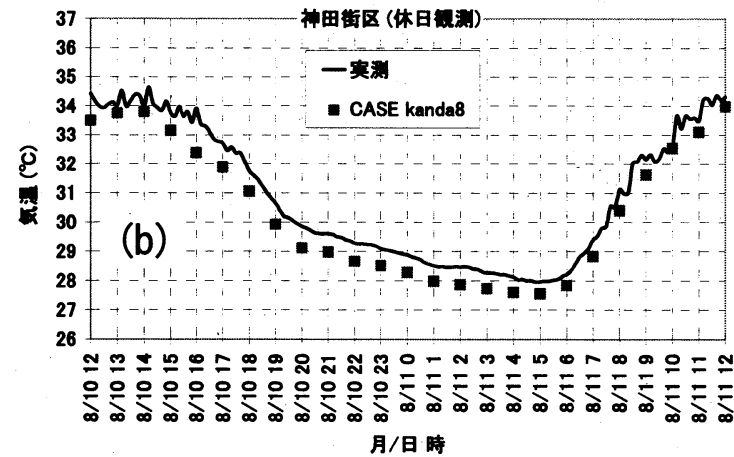

図-5 (a) 平日・(b) 休日観測期間中の高度35mでの気温の 観測結果（実線）と計算結果（マーカー）（a）の 四角のマーカーが冷房負荷・排熱を考慮した場 合, 三角のマーカーはそれらを考慮しない場合の計 算結果.（b)の四角のマーカーは休日のため, 冷房 負荷・排熱を考慮しない場合の計算結果.

\section{5. 気象条件の変化に伴う冷房排熱の気温への影}

\section{響変化}

図-3で見られるように，平日観測期間の泠房排熱によ る日中の気温上昇は，モデル計算から約 $1 \sim 2^{\circ} \mathrm{C}$ 程度と推 定できる. しかしこれはこの日に限って言えることであ り, 排熱による温度上昇の程度は, 風速や日射量といっ た気象条件に大きく左右されることが予想される.この ことは，気温上昇をもたらす冷房排熱のポテンシャルを 理解する上で重要な要素と言える. 図-6に，観測期間を 含む 2002 年梅雨明け以降の夏季気象条件（地上風速, 日 積算日射量, 地衡風風速) の変化を示す. 2002年は例年 よりも真夏日が多く猛暑の年と言えるが，それでも AMeDAS大手町で全期間中（43日）の31\%（13日）は曇 が支配する天候であった. 図-6を見てもわかるように， 同じ夏季であっても1日の日射量, 風速が日によって大 きく異なっている. そこで, とり得る気象条件の範囲内 で泠房排熱による気温上昇がどの程度変化するか検討を おこなった。

気象条件として, 日射量と風速の増減を評価の対象と した. 平日観測期間中は量天で, 日射量, 風速ともに夏

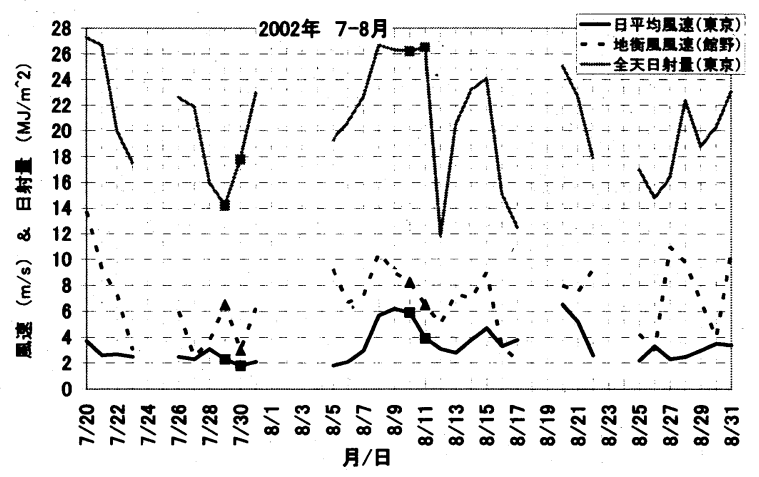

図一6 2002年梅雨明け以降夏季（7月20日～8月 31 日）におけ る日平均地上風速, 日積算全天日射量（東京管区気 象台）, 日平均地衡風風速（館野; $700 \mathrm{hPa}$ 高度での $3,9,15,21$ 時の平均值) の推移. 降雨のあった日 を除く.マーカーが観測期間中の值を示している.

季の中で最低に近い.この期間を曇天弱風日と定義して， 晴天弱風日, 曇天強風日, 晴天強風日の3つの気象条件 を想定したシミュレーションをおこない, 冷房排熱の気 温への影響の変化を検討した. 晴天条件には休日観測期 間に測定された日射量をモデル計算に用いた. モデル上 端境界の風速は700hPa高度の地衡風風速から推定してお り，平日観測期間中は約 $5 \mathrm{~m} / \mathrm{s}$ であった. 2002 年梅雨明け 以降夏季の同高度の最大風速は約 $14 \mathrm{~m} / \mathrm{s}$ となっており

(図-6参照)，これを強風日とした。

表-3は, 各気象条件でのシミュレーションで得られた, 冷房負荷・排熱を考慮した場合と考慮しない場合の地上 気温の差をまとめたものである. 表からわかるように, 日射量が大きいと日中の冷房排熱の気温上昇への寄与が 小さくなる傾向が見られる．これは，日射量が大きい晴 天日には対流混合層がよく発達することで排熱が高くに まで拡散され，混合層高度の低い曇天日に比べて大気加 熱が抑えられるためと考えられる.この物理過程は午前 と午後の冷房排熱による気温上昇度の違いにも当てはま り, 混合層が高くまで発達している午後の方がその気温 上昇が小さくなっている.

一方で，曇天日にほとんど気温差が現れなかった夜間 は，晴天日になるとBEMを連成させない方が気温が高 くなっている，すなわち，夜間には冷房排熱が存在して いないにもかかわらず，気温に差が生じている. 図-7に, 曇天弱風日 (濃い線) と晴天弱風日 (薄い線) の計算に おいてBEMを連成させた場合と連成させない場合のビ ル表面から大気力ラムに供給される顕熱フラックスの差 を示す. 図からわかるように，曇天日の夜間は大気に供 給される顕熱フラックスは冷房負荷・排熱の考慮の有無 でほとんど差がないのに対して，晴天日には冷房負荷・ 排熱を考慮しないほうが大気に供給される顕熱が $40 \mathrm{~W} / \mathrm{m}^{2}$ 近くも増加している. 日中, 曇天日よりも晴天日のほう がビルは日射による加熱の影響を受け，冷房負荷・排熱 
表-3 冷房負荷・排熱の考虑の有無によって生じる地上気温 の差（連成有一連成無; 神田街区での結果）．網掛け が基準計算 (今まで述べてきた平日計算) の結果. 矢 印は基淮計算の結果に対しての絶対值の増减 $\left(0.2^{\circ} \mathrm{C}\right.$ 以 上増加は $\uparrow ； 0.2^{\circ} \mathrm{C}$ 以上減少は $\left.\downarrow\right)$ を示している.

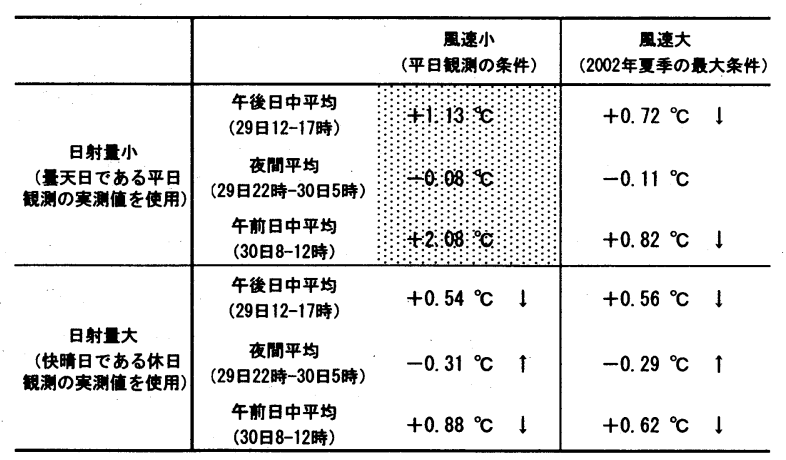

を考慮しない場合には冷房運転がないため室内を含めた ビル内の温度が上昇する. その結果, 夜間の放熱が目 立って大きくなったと考えられる.

風速による寄与は日射に比べると小さいが，風速が大 きくなると総じて日中の排熱による気温上昇を $1^{\circ} \mathrm{C}$ 未満 に抑える効果を持つことが表-3からわかる.

これらの結果から, 日中は風が弱く日射量が小さい気 象条件ほじ冷房排熱による気温上昇が現われやすく，今 回対象の神田街区では最大で $2^{\circ} \mathrm{C}$ 程度の上昇が予想され る. 逆に, 風が強く日射量が大きい気象条件は最も排熱 の影響が小さくなり， $0.5^{\circ} \mathrm{C}$ 程度の上昇となることが明 らかとなった。

\section{6. まとめ}

都市気象・ビルエネルギー連成モデルを用いて，事務 所街区を対象とした冷房排熱に伴う気温変化のシミュ レーションをおこなった. その結果を以下にまとめる.

1. ビル内でのエネルギー消費やそれに伴う冷房排熱が 存在する平日期間（2002年7月29〜30日），それらが 存在しない休日期閒（同8月10１1日）の両方に対し て, 連成モデルは実測気温をよく再現することができ た. 従って, この連成モデルが今後, 街区内熱環境の 定量的な予測や評価に十分有効であることが言える.

2. シミュレーションから，平日観測期間中の冷房排熱 による日中の気温上昇は $1 \sim 2^{\circ} \mathrm{C}$ 程度であったものと推 定された. ただし, 排熱の気温上昇への寄与度は気象 条件（日射量，風速）に大きく依存しており，日射量， 風速が大きくなる (晴天条件, 強風条件) と排熱の影 響が抑えられる（本シミュレーションでは $0.5^{\circ} \mathrm{C}$ 程度 の気温上昇）ことが明らかとなった.

従来の都市気候・熱環境の研究では, そのほとんどが好

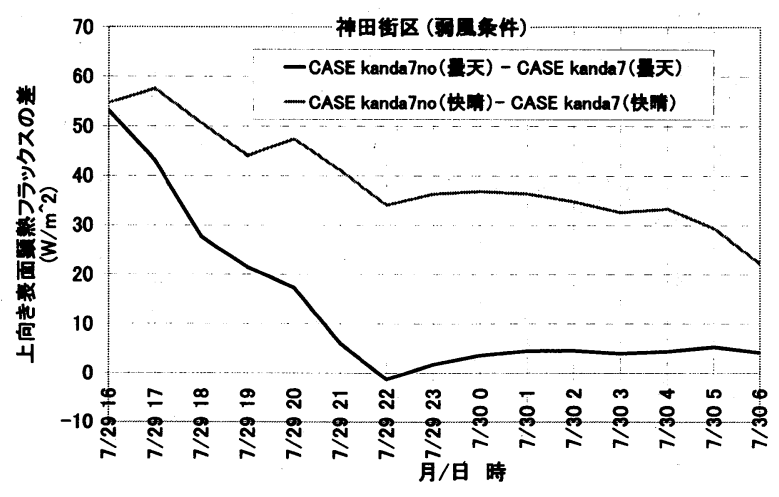

図-7 冷房負荷・排熱の考慮の有無によって生じるビル表面か らモデル大気カラムへ供給される顕熱フラックス（単 位格子面積当たり）の差の時間変化. 曇天弱風日（濃 い実線）と快晴弱風日（薄い実線）の計算結果に対し て.

天静穏日条件でのヒートアイランド対策などの気温低减 効果がシミュレーションによって評価されている. しか し, 本稿で明らかになったように, その効果は気象条件 に大きく左右されることが予想されるため, 様々な気象 条件下での評価が今後必要であると言える.

謝辞 : 観測に際し，ご尽力を頂きました（独）産業技術 総合研究所の武藤勝彦氏, 高井淳氏, 飯塚悟氏, 防衛大 学校の菅原広史助手, 日本工業大学建築学科 - 武蔵工業 大学の学生方, 本論文作成にあたり有益なご意見を頂き ました (財) 電力中央研究所の日下博之氏に対して深謝 致します. 本研究の一部は環境省地球環境保全・公害防 止等試験研究費（課題番号26）並びに（財）住友財団環 境研究助成（助成番号033342）を受けておこないました.

\section{参考文献}

1) 近藤裕昭・劉発華 : 1次元都市キャノピーモデルによる都市 の熱環境に関する研究, 大気環境学会誌, Vol.33, pp.179192, 1998.

2) 亀卦川幸浩・玄地裕・吉門洋・近藤裕昭: 建築空調エネル ギ一需要への影響を考慮した都市高温化対策評価手法の開発, エネルギー・資源，Vol.22，pp.235-240，2001.

3) Ashie, Y., Ca, V.T. and Asaeda, T.: Numerical analysis of heat island phenomena for the control of cooling energy in cities, J. Glob. Environ. Eng., Vol.7, pp.101-117, 2001.

4) 環境省 : 環境省ヒートアイランド対策委員会報告書, 2001 .

5) 榊原保志 : 越谷市に見られるヒートアイランド強度一郊外 が水田の場合一. 天気, Vol.41, pp.515-523， 1994.

6) Jurges, W.: Der Warmeuberergang an einer ebeneb Wand, Beihefte zum Gesundheits-Ingenieur, Beiheft 19, 1924.

7) Gambo, K: Notes on the turbulence closure model for atmospheric boundary layers. J. Meteorol. Soc. Japan, Vol.56, pp.466-480, 1978.

8) 大橋唯太・玄地裕・亀卦川幸浩 : 東京都心の街区内気温の 空間分布とその形成要因について, 環境情報科学, Vol.17, pp.59-64, 2003.

(2003. 9. 30受付) 